Thabiea: Journal of Natural Science Teaching
Program Studi Tadris Ilmu Pengetahuan Alam
Institut Agama Islam Negeri Kudus
http://journal.stainkudus.ac.id/index.php/Thabiea
$p-i s s n: 2580-8974, e-i s s n: 2655-898 x$

\title{
Penerapan Pembelajaran dengan Metode Mindmapping Menggunakan Coggle TM
}

Dewi Dewantara ${ }^{\text {a, }}$ *

a Pendidikan Fisika FKIP Universitas Lambung Mangkurat

${ }^{1}$ dewantarafisika@gmail.com*

\begin{tabular}{ll}
\hline Informasi artikel & ABSTRAK \\
\hline Kata kunci: & Artikel ini bertujuan untuk mendeskripsikan ada atau tidaknya perbedaan \\
Mind mapping & antara hasil belajar sebelum dan setelah menerapkan pembelajaran dengan \\
Coggle TM & metode mindmapping menggunakan Coggle TM. Jenis penelitian ini adalah \\
Hasil belajar & pre-eksperimen dengan metode one group pre-test post-test design. Jumlah \\
& sampel penelitian adalah 15 orang mahasiswa. Teknik pengumpulan data \\
& adalah dengan menggunakan pre-test dan post-test. Data dianalisis dengan \\
& menggunakan uji-t berpasangan. Hasil analisis uji-t diperoleh nilai $\mathrm{t}=-$ \\
& 5,985 dengan sig $(2-$-tailed) $=0,000$ yang lebih kecil dari taraf signifikansi \\
& yakni 0,05. Simpulan dari hasil penelitian ini adalah terdapat perbedaan \\
antara kemampuan analisis awal dan kemampuan analisis akhir mahasiswa & setelah menerapkan Pembelajaran dengan metode mindmapping \\
& menggunakan Coggle TM.
\end{tabular}

Key word:

Mind mapping

Coggle TM

Learning outcome

\begin{abstract}
Application of Learning with the Mindmapping Method Using Coggle тм. This article aims to describe whether or not there are differences between learning outcomes before and after applying learning with the mindmapping method using coggle. The type of this research is preexperiment with one group pre-test post-test design method. The number of research samples is 15 students. The data collection technique is to use the pre-test and post-test. Data were analyzed using paired t-test. The results of the $\mathrm{t}$-test analysis obtained the value $\mathrm{t}=-5,985$ with sig $(2$-tailed $)=0,000$ which is smaller than the significance level of 0.05 . The conclusion of the results of this study is that there is a difference between the initial analytical skills and the final analysis ability of students after applying Learning with the mindmapping method using the coggle application.
\end{abstract}

\section{Copyright $\odot 2019$ Institut Agama Islam Negeri Kudus. All Right Reserved}

\section{Pendahuluan}

Salah satu mata kuliah di program studi pendidikan fisika yang mempelajari dan menelaah materi ajar di SMA adalah adalah Telaah Fisika SM III. Adapun capaian pembelajaran mata kuliah Telaah Fisika SM III adalah mahasiswa mampu menguasai berbagai kompetensi pembelajaran, strategi pencapaian kompetensi, dan karakteristik materi ajar Fisika SMA Kelas III, serta mampu menjawab/menyelesaikan berbagai pertanyaan dan persoalan yang menyangkut materi ajar tersebut beserta pembelajarannya.

Salah satu materi yang dipelajari di mata kuliah Telaah Fisika SM III adalah induksi elektromagnetik. Kompetensi dasar sesuai dengan Kurikulum 2013 dari materi ini adalah menganalisis fenomena induksi elektromagnetik dalam kehidupan seharihari. Oleh karena itu, mahasiswa calon guru fisika harus memiliki kemampuan dalam menganalisis berkaitan dengan materi tersebut. Kemampuan ini akan terlihat pada 
hasil belajar mahasiswa setelah melaksanakan mata kuliah Telaah Fisika SM III khususnya pada materi induksi elektromagnetik. Keberhasilan belajar fisika di SMA umumnya diukur dari seberapa jauh menguasai konsep yang diajarkan (Hasanah, Supeno, \& Wahyuni, 2015).

Hasil belajar biasanya digunakan sebagai ukuran untuk mengetahui seberapa jauh seseorang menguasai bahan yang sudah diajarkan (Dewantara, Jamal, \& Annur, 2013). Hasil belajar dapat ditngkatkan dengan menggunakan salah satu strategi pembelajaran seperti mind mapping (Miranti \& Wilujeng, 2018). Mind map membebaskan mahasiswa untuk mengkontruksi ide atau konsepnya sendiri sehingga mudah untuk dipahami (Putri, Masril, \& Gusnedi, 2017). Ide-ide maupun konsep yang dihasilkan mahasiswa akan dituangkan dalam bentuk mindmap, sehingga mahasiswa menjadi lebih mudah mengingat materi (Annisa, Heryanto, Rusilowati, \& Subali, 2018; Imaniarti, Prihandono, \& Supriadi, 2015; Rohman, Ain, \& Cahyo, 2017).

Mind mapping membuat mahasiswa lebih mudah mengingat pelajaran dan menerapkannya ketika siswa menghadapi ujian hasil belajar fisika (Pebriayani, Arsyad, \& Khaeruddin, 2012). Mind mapping mempermudah siswa dalam memahami berbagai hubungan-hubungan pada materi yang dipelajari (Hasanah et al., 2015). Mind mapping sangat berpotensi untuk membantu mahasiswa dalam memecahkan masalah dan membuat keputusan terkait dengan masalah tersebut (Herdin, 2017). Selain itu, penggunaan Mind mapping akan menyebabkan proses belajar yang menyenangkan dan mendorong anak untuk mandiri belajar serta sukses dalam prestasi akademiknya (Windura, 2016).
Mind mapping dapat mendukung konstruktivisme berdasarkan desain pembelajaran (Miranti \& Wilujeng, 2018). Salah satu bantuan berbentuk website yang dapat dipakai adalah Coggle TM. Proses pembuatan mind mapping menggunakan Coggle TM, tidak hanya fokus pada tampilan tetapi juga dilengkapi dengan kemampuan interaktif dari perangkat lunak yang difasilitasi kolaborasi, diskusi pembuat mind mapping (Sutton, Fraser, \& Corbett, 2017). Coggle тм juga memungkinkan pengintegrasian dengan berbagai gambar dan tautan (link) melalui cabang-cabang dari mind mapping (Aisyah, Kamrozzaman, Badusah, \& Ruzanna, 2019). Coggle тм 8 memungkinkan pembuat mind mapping untuk secara grafis memvisualisasikan dan mengungkapkan berbagai hal yang mungkin disampaikan oleh data (Sutton et al., 2017).

Penerapan metode mind mapping menggunakan Coggle TM diuji pengaruhnya terhadap hasil belajar mahasiswa. Artikel ini bertujuan untuk mendeskripsikan ada atau tidaknya perbedaan antara hasil belajar mahasiswa sebelum dan setelah menerapkan Pembelajaran dengan metode mind mapping menggunakan Coggle TM.

\section{Metode}

Jenis penelitian ini adalah preeksperimen dengan metode one group pretest post-test design. Pada metode ini Sebuah kelompok penelitian dilakukan pre-test $\left(0_{1}\right)$ terlebih dahulu sebelum diberikan perlakuan (X) dan kemudian dilakukan lagi post-test $\left(\mathrm{O}_{2}\right)$.

\section{$\begin{array}{lll}0_{1} & \mathrm{X}_{2} & 0_{2}\end{array}$}

Penelitian dilakukan pada mahasiswa pendidikan Fisika yang menempuh mata kuliah telaah Fisika Sekolah Menengah III pada tahun 2018. Jumlah sampel penelitian 
adalah 15 orang mahasiswa. Teknik pengumpulan data adalah dengan menggunakan pre-test dan post-test untuk mengetahui hasil belajar mahasiswa sebelum dan sesudah menerapkan Pembelajaran dengan metode mind mapping menggunakan Coggle TM. Materi dalam penelitian ini di batasi pada materi induksi elektromagnetik.

Data dianalisis dengan menggunakan uji-t berpasangan. Hipotesis null $\mathrm{H}_{\mathrm{o}}$ dalam penelitian ini adalah tidak terdapat perbedaan antara hasil belajar sebelum dan setelah menerapkan pembelajaran dengan metode mind mapping menggunakan Coggle тм. Hipotesis alternatif $\mathrm{H}_{\mathrm{a}}$ dalam penelitian ini adalah terdapat perbedaan antara hasil belajar sebelum dan setelah menerapkan Pembelajaran dengan metode mind mapping menggunakan aplikasi Coggle TM.

\section{Hasil dan pembahasan}

Pembelajaran dengan metode mind mapping menggunakan Coggle тм di laksanakan pada materi rangkaian induksi elektromagnetik. Coggle TM merupakan versi publik yang tak terbatas yang memudahkan mind mapping dibagikan. Selain itu, Coggle тм menyediakan fitur multi-warna dan mudah digunakan. Gambar 1 menunjukkan hasil mind mapping menggunakan Coggle TM yang digunakan dalam pembelajaran induksi elektromagnetik.

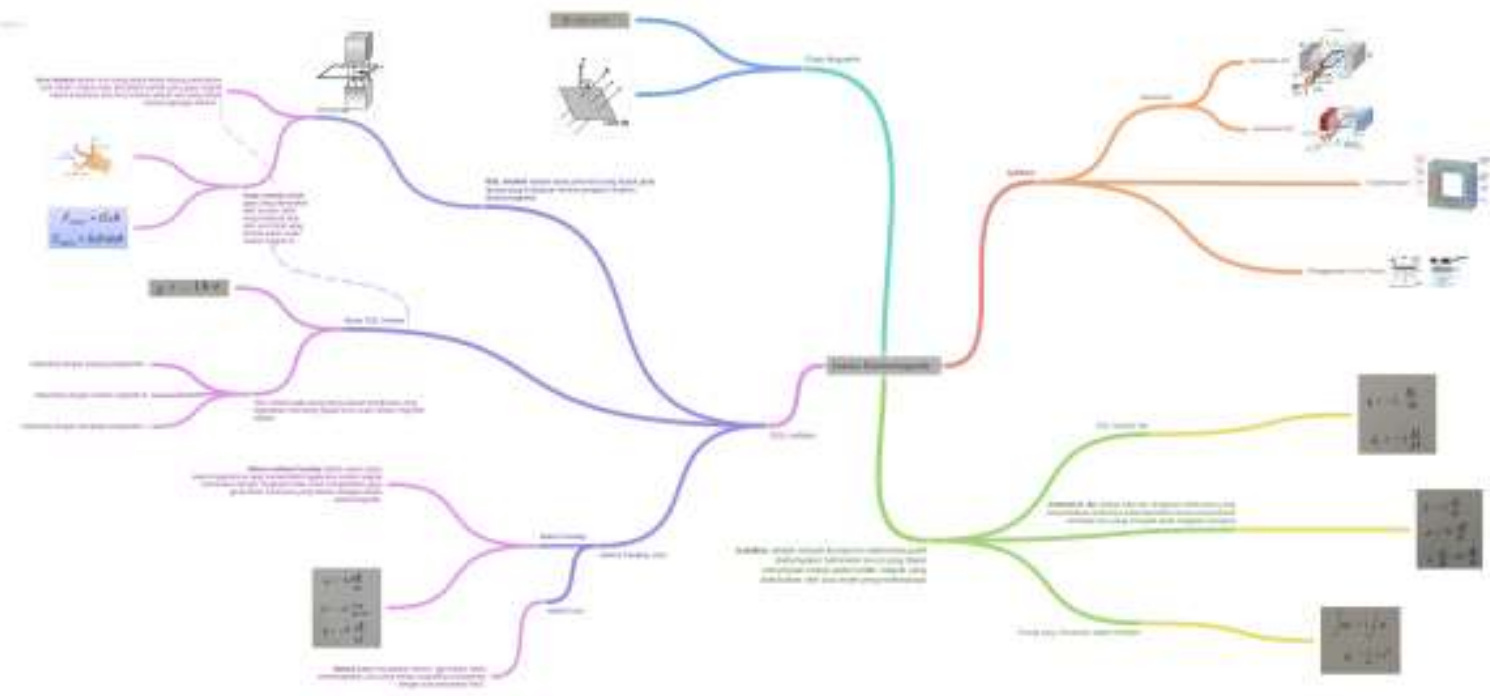

Gambar 1. Tampilan mind mapping Coggle TM

Sumber: https://coggle.it/diagram/W1ZusKfTAn7fAFQ8/t/induksi-elektromagnetik

Tabel 1. Hasil Uji-t berpasangan

\begin{tabular}{lllll}
\hline & & t & df & $\begin{array}{l}\text { Sig. (2- } \\
\text { tailed) }\end{array}$ \\
\hline Pair 1 & $\begin{array}{l}\text { Pretest - } \\
\text { posttest }\end{array}$ & $-5,985$ & 14 & 0,000 \\
\hline
\end{tabular}

Hasil uji-t berpasangan ditunjukkan pada Tabel 1. Hasil analisis uji-t diperoleh nilai $\mathrm{t}=-5,985$ dengan sig $(2$-tailed $)=0,000$ yang lebih kecil dari taraf signifikansi yakni
0,05. Dengan demikian Hipotesis Nol di tolak, hipotesis alteratif diterima. Hasil analisis paired sample t-test, diperoleh bahwa terdapat perbedaan antara pre-test dan post-test mahasiswa setelah menerapkan Pembelajaran dengan metode Coggle ${ }^{\mathrm{TM}}$ menggunakan Coggle TM.

Penggunaan mind mapping dapat membantu siswa dalam meningkatkan hasil belajar. Hal ini sejalan dengan penelitian 
sebelumnya yang menunjukkan bahwa penerapan metode pembelajaran dengan peta pikiran (mind mapping) telah tercapai dengan hasil belajar siswa yang selalu mengalami peningkatan (Ulya, Santoso, \& Hamidi, 2015). Mind mapping membuat pembelajaran lebih menarik dalam memahami materi dan dapat meningkatkan pemahaman siswa akan materi pelajaran yang diajarkan dalam proses pembelajaran(Sinaga \& Simatupang, 2014). Mind mapping dalam dunia pendidikan akan mempermudah siswa dalam menerima pelajaran, melihat fakta-fakta lebih jelas dan memberikan pemahaman yang lebih dalam kepada siswa (Oktisa, Hidayati, \& Razi, 2015).

Ada banyak manfaat dari penggunaan mind mapping. Penggunaan mind mapping dapat membuat mahasiswa menyadari keterkaitan antara satu konsep dengan konsep lainnya dalam materi ajar dengan tetap memahami konteksnya dan memusatkan perhatian sehingga tetap fokus dalam proses pembelajaran (Mariyam \& Nuraida, 2017; Sitindaon \& Sirait, 2015). Mind mapping juga membantu guru untuk melihat sejauh mana pengetahuan mahasiswa terhadap materi yang dipelajari (Rahma, 2013).

Mind mapping yang digunakan dalam pembelajaran memberikan dampak positif bagi siswa (Mariyam \& Nuraida, 2017). Mind Mapping membuat pembelajaran menjadi kreatif dan mudah mengingat secara alami melalui warna dan gambar yang menyenangkan sehingga merangsang pemikiran yang detail, jelas, dan sederhana terhadap apa yang dipelajari (Herdin, 2017). Melalui mind mapping, mahasiswa tidak hanya mendengar penjelasan, tetapi ikut berperan aktif dalam proses pembelajaran supaya lebih memahami dan menguasai materi (Choiroh, Ayu, \& Pratiwi, 2018).

Banyak perangkat mind mapping yang diadopsi ke dalam proses pembelajaran (Maksimenkova, Neznanov, Papushina, \& Parinov, 2011). Salah satu situs yang menyediakan layanan pembuatan mindmapping adalah Coggle TM. Menurut hasil uji-t, Coggle TM mampu meningkatkan hasil belajar siswa. Coggle TM adalah mind mapping online kolaboratif yang digunakan untuk membuat ide, mengintegrasikan informasi, atau merencanakan tugas (Aisyah et al., 2019). Coggle тм pada awalnya membantu dalam membuat mind mapping visual sederhana untuk menggambarkan apa yang telah ditemukan, serta mengkategorikan apa yang telah diperoleh (Sutton et al., 2017).

\section{Simpulan}

Simpulan dari hasil penelitian ini adalah terdapat perbedaan antara kemampuan analisis awal dan kemampuan analisis akhir mahasiswa setelah menerapkan Pembelajaran dengan metode Mind mapping menggunakan aplikasi Coggle TM. Hal ini dilihat dari hasil uji t yang memperoleh nilai $\mathrm{t}=-5,985$ dengan sig $(2-$ tailed) $=0,000$ yang lebih kecil dari taraf signifikansi yakni 0,05 . Berdasarkan hasil penelitian ini disarankan agar dapat mencoba menggunakan metode mind mapping menggunakan Coggle тм dalam pembelajaran untuk meningkatkan hasil belajar mahasiswa.

\section{Referensi}

Aisyah, N., Kamrozzaman, Badusah, J., \& Ruzanna, W. M. (2019). Coggle: SWOT analysis in lifelong learning education using online collaborative mind-mapping Keyword s. International Journal of Asian Social 
Science, $\quad 9(1), \quad$ 139-147. https://doi.org/10.18488/journal.1.201 9.91.139.147

Annisa, R., Heryanto, W. P., Rusilowati, A., \& Subali, B. (2018). Peningkatan daya ingat dan hasil belajar siswa dengan mind mapping method pada materi listrik dinamis. Jurnal Pendidikan (Teori Dan Praktik), 3(1), 19-23.

Choiroh, A. N. L., Ayu, H. D., \& Pratiwi, H. Y. (2018). Pengaruh model pembelajaran flipped classroom menggunakan metode mind mapping terhadap prestasi dan kemandirian belajar fisika. Jurnal Pendidikan Fisika, 7(1), 1-5.

Dewantara, D., Jamal, M. A., \& Annur, S. (2013). Meningkatkan hasil belajar siswa kelas XI IPA-1 SMA Negeri 1 Jorong melalui pembelajaran kooperatif tipe somatic auditory visual and intellectual pada pokok bahasan impuls dan momentum. Berkala Ilmiah Pendidikan Fisika, 1(2), 159-168.

Hasanah, N. N., Supeno, \& Wahyuni, S. (2015). Kekuatan retensi siswa SMA kelas X dalam pembelajaran fisika pada pokok bahasan momentum dan impuls menggunakan lembar kerja siswa berbasis mind mapping. Jurnal Pembelajaran Dan Pendidikan Sains, 2(1), 25-32.

Herdin. (2017). 7 Rahasia Mind Map Membuat Anak Genius. Jakarta: PT Elex Media Komputindo.

Imaniarti, E., Prihandono, T., \& Supriadi, B. (2015). penerapan model pembelajaran inkuiri terbimbing disertai teknik mind mapping terhadap kemampuan kognitif, afektif, dan psikomotor siswa dalam pembelajaran fisika Di SMAN Arjasa. Jurnal Pembelajaran Fisika, 4(3), 192-197.

Maksimenkova, O., Neznanov, A., Papushina, I., \& Parinov, A. (2011). On Mind Maps Evaluation: A Case of an Automatic Grader Development.
Teaching and Learning in a Digital World: Proceedings of the 20th International Conference on Interactive Collaborative Learning, 2.

Mariyam, \& Nuraida, D. (2017). Pengaruh Model Pembelajaran Brain Based Learning Dipadukan dengan Mind Mapping terhadap Penguasaan Konsep Siswa The Influence of Learning Learning Model of Braind Based Learning with Mind Mapping on Student Concept Construction. Proceeding Biology Education Conference, 14(1), 494-497.

Miranti, M. G., \& Wilujeng, B. Y. (2018). Creative Thinking Skills Enhancement Using Mind Mapping. In 1st International Conference on Social, Applied Science and Technology in Home Economics (ICONHOMECS 2017) Creative (Vol. 112, pp. 39-42).

Oktisa, M., Hidayati, \& Razi, F. (2015). Pembuatan bahan ajar dalam bentuk brosur menggunakan mind map untuk pembelajaran IPA siswa kelas VIII di SMP Negeri 8 Padang Staf Pengajar Jurusan Fisika, FMIPA Universitas Negeri Padang. Pillar Of Physics Education, 6, 129-136.

Pebriayani, H., Arsyad, M., \& Khaeruddin. (2017). Peningkatan Hasil Belajar Fisika Melalui Metode Pembelajaran Mind Mapping Pada Siswa Kelas VIIIa SMPN 33 Makassar. JPS, 1(2), 169179.

Putri, W. R., Masril, \& Gusnedi. (2017). Pengaruh penggunaan LKPD berbasis mind map pada pembelajaran berbasis masalah terhadap pencapaian kompetensi fisika peserta didik kelas XI SMA Negeri 2 Padang pada materi teori kinetik gas dan pemanasan global. Pillar Of Physics Education, 10, 169176.

Rahma, A. A. (2013). Pengaruh Model Siklus Belajar Berbantuan Mind Map terhadap Prestasi Belajar Fisika 
Ditinjau dari Kinerja Laboratorium Siswa Kelas VIII SMPN 1 Rejoso Kabupaten Pasuruan. Jurnal Pendidikan Sains, 1(2), 187-193.

Rohman, A., Ain, T. N., \& Cahyo, H. A. (2017). Upaya membangkitkan kreativitas dan motivasi berprestasi mahasiswa calon guru fisika dengan pembelajaran Attention, Relevance, Confidence , Satisfaction ( ARCS ) melalui Mindmap. In SEMINAR NASIONAL FISIKA (SNF) 2017 "Menghilirkan Penelitian-Penelitian Fisika dan Pembelajarannya” (pp. 5459).

Sinaga, N. R. S. S., \& Simatupang, S. (2014). Pengaruh model pembelajaran kooperatif tipe two stay two stray berbantuan mind mapping terhadap hasil belajar siswa pada materi listrik dinamis kelas $\mathrm{X}$ semester II SMA Negeri 2 Sidikalang T.P. 2012/2013. Inpafi, 2(1).
Sitindaon, R. S. H., \& Sirait, M. (2015). Pengaruh model problem based learning berbantu mind map terhadap hasil belajar siswa pada materi pokok fluida dinamik. INPAFI (Inovasi Pembelajaran Fisika), 3(3).

Sutton, G., Fraser, S., \& Corbett, M. (2017). Disrupting Perception: Mapping An Understanding Of Educational Attainment. Australian and International Journal of Rural Education, 27(2).

Ulya, A., Santoso, S., \& Hamidi, N. (2015). Peningkatan hasil belajar melalui penerapan metode peta pikiran pada pembelajaran dasar-dasar perbankan. Jurnal "Tata Arta" UNS, 1(3), 332342.

Windura, S. (2016). Mind Map Langkah Demi Langkah. Jakarta: PT Elex Media Komputindo. 